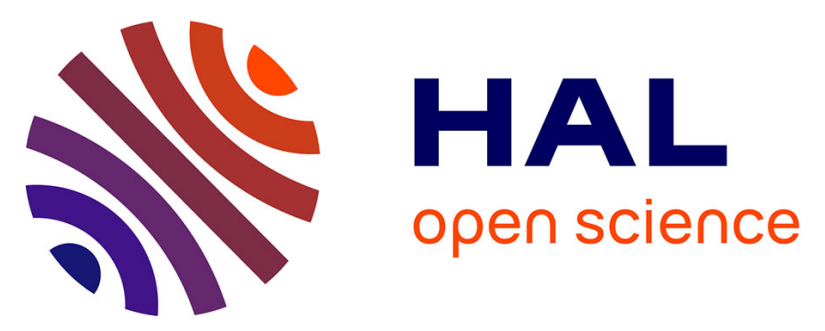

\title{
Impact damage characterization in hybrid fiber-reinforced composites using terahertz imaging in time and frequency domain
}

\author{
Junliang Dong, A. Locquet, Nico Declercq, D. Citrin
}

\section{To cite this version:}

Junliang Dong, A. Locquet, Nico Declercq, D. Citrin. Impact damage characterization in hybrid fiberreinforced composites using terahertz imaging in time and frequency domain. 2015 40th International Conference on Infrared, Millimeter, and Terahertz waves (IRMMW-THz), Aug 2015, Hong Kong, China. 10.1109/IRMMW-THz.2015.7327396 . hal-03085257

\section{HAL Id: hal-03085257 https://hal.science/hal-03085257}

Submitted on 21 Dec 2020

HAL is a multi-disciplinary open access archive for the deposit and dissemination of scientific research documents, whether they are published or not. The documents may come from teaching and research institutions in France or abroad, or from public or private research centers.
L'archive ouverte pluridisciplinaire HAL, est destinée au dépôt et à la diffusion de documents scientifiques de niveau recherche, publiés ou non, émanant des établissements d'enseignement et de recherche français ou étrangers, des laboratoires publics ou privés. 


\title{
Impact Damage Characterization in Hybrid Fiber Composites Using Terahertz Imaging in the Time and Frequency Domains
}

\author{
Junliang Dong ${ }^{1,2}$, Alexandre Locquet ${ }^{1,2}$, Nico F. Declercq ${ }^{1,3}$ and D. S. Citrin ${ }^{1,2, *}$ \\ ${ }^{1}$ UMI 2958 Georgia Tech-CNRS, Georgia Tech Lorraine, 2 Rue Marconi, 57070 Metz, France \\ ${ }^{2}$ School of Electrical and Computer Engineering, Georgia Institute of Technology, Atlanta, GA, 30332 USA \\ ${ }^{3}$ Woodruff School of Mechanical Engineering, Georgia Institute of Technology, Atlanta, GA, 30332 USA \\ *Email: david.citrin@ece.gatech.edu
}

\begin{abstract}
A hybrid fiber composite laminate with impact damage has been studied via terahertz imaging. Terahertz $C$-scan and B-scan images are obtained in both the time and frequency domains. Factors including the terahertz polarization, fiber orientation and arrangement are considered to compare and analyze the images in an impact-damaged sample.
\end{abstract}

\section{INTRODUCTION}

$\mathrm{T}$ ERAHERTZ imaging, which can provide a noninvasive, noncontact, and nonionizing method to imaging composites, is a promising modality for nondestructive evaluation of fiber composites. For carbon fiber composites, due to its conductivity, $\mathrm{THz}$ can only be used to detect near-surface defects; for glass fiber composites, $\mathrm{THz}$ can penetrate further to detect buried and underlying defects [1].

In this study, $\mathrm{THz}$ imaging is performed to detect impact damage in a hybrid fiber composite laminate, comprised of unidirectional glass/epoxy and carbon/epoxy laminae with a 'cross-ply' stack pattern $\left[0^{\circ}{ }_{2}{ }_{2} / 90^{\circ}{ }_{3} / 0^{\circ}{ }_{2}\right]_{\mathrm{s}}$. The dimension of the laminate is $120 \mathrm{~mm} \times 120 \mathrm{~mm} \times 1.65 \mathrm{~mm}$. Damage was generated by controlled free-fall impact: an impactor of $50 \mathrm{~g}$ struck the laminate at a $2.5 \mathrm{~m} / \mathrm{s}$. Two indentations are visible on the bottom surface. $\mathrm{THz} \mathrm{C}$ - and B-scans of the impact damage are obtained by a standard THz TDS system in the time and frequency domains.

\section{RESULts}

The penetration of $\mathrm{THz}$ waves in carbon fiber composites depends on the relation of the $\mathrm{THz}$ polarization and the carbon fiber orientation [2]. When the direction of carbon fibers is parallel to the $\mathrm{THz}$ polarization, nearly total reflection is obtained; when the direction of carbon fibers is perpendicular to the $\mathrm{THz}$ polarization, the reflection coefficient decreases and $\mathrm{THz}$ waves can reach the sub-surface of the laminae.
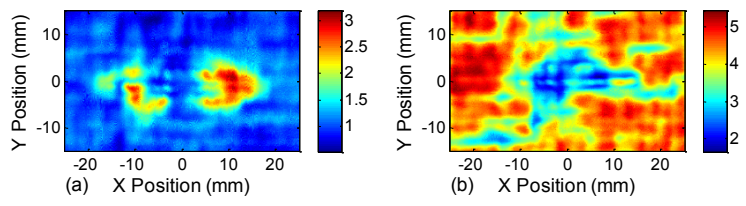

Fig. 1. Time domain C-scan images with polarization (a) perpendicular to and (b) parallel to the direction of carbon fibers.

Time domain C-scans based on the reflected waves from the interface between the glass/epoxy and carbon/epoxy laminae are shown in Fig.1 with different polarization of $\mathrm{THz}$ waves. Fig.1 (a) shows the delaminations appearing at the interface; Fig.2 (b) emphasizes the damage areas on the surface of the carbon fiber lamina, which lose the total reflection due distorted carbon fiber by the impact damage.
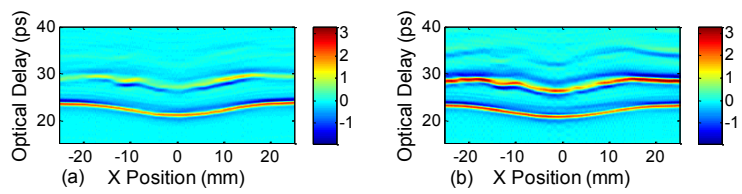

Fig. 2. Time domain B-scan images with polarization (a) perpendicular to and (b) parallel to the direction of carbon fibers.

Time domain B-scan images are shown in Fig.2 indicating the dependence of the reflection coefficient on the $\mathrm{THz}$ polarization. Surface deformation and delamination can also be identified.
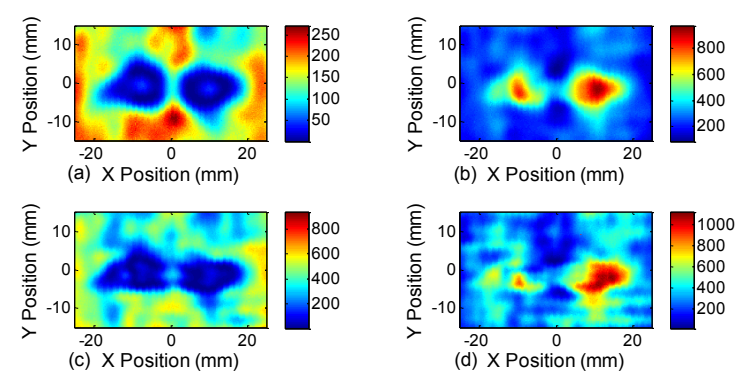

Fig. 3. Frequency domain $\mathrm{C}$-scans with polarization perpendicular to the direction of carbon fibers at (a) 0.22 , (b) 0.3 , (c) 0.38 , (d) $0.48 \mathrm{THz}$.

Frequency domain C-scan images with different polarization are shown in Fig.3 and Fig.4. With the increase of frequency, the penetration depth will decrease. Therefore, C-scan images at different frequencies can provide a method to evaluate the impact damage in different depth.
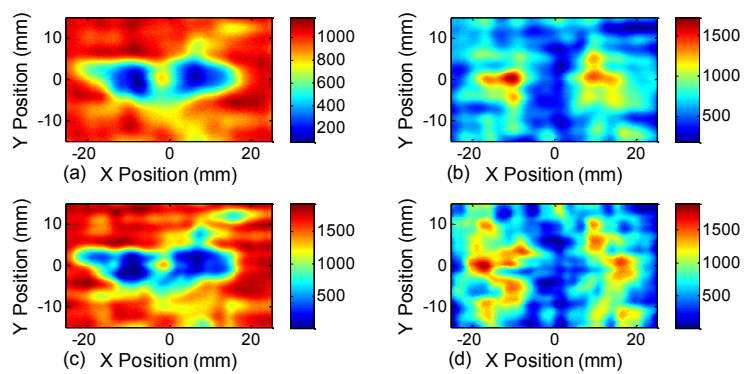

Fig. 4. Frequency domain $\mathrm{C}$-scans with polarization parallel to the direction of carbon fibers at (a) 0.2 , (b) 0.28 , (c) 0.36 , (d) $0.46 \mathrm{THz}$.

\section{REFERENCES}

[1]. I. Amenabar, F. Lopez, and A. Mendikute, "In Introductory Review to THz Non-Destructive Testing of Composite Materials," J Infrared Milli Terahz Waves 34, 152-169 (2013).

[2]. S.-H. Yang, K.-B. Kim, H. G. Oh, and J.-S. Kang, "Non-contact detection of impact damage in CFRP composites using millimeter-wave reflection and considering carbon fiber direction," NDT \& E International 57, 45-51 (2013). 